University of Louisville

ThinkIR: The University of Louisville's Institutional Repository

$5-2020$

\title{
How nondiscrimination takes root: an examination of methods to implement statewide nondiscrimination legislation in Kentucky.
}

Blake Nona Gould

University of Louisville

Follow this and additional works at: https://ir.library.louisville.edu/etd

Part of the Administrative Law Commons

\section{Recommended Citation}

Gould, Blake Nona, "How nondiscrimination takes root: an examination of methods to implement statewide nondiscrimination legislation in Kentucky." (2020). Electronic Theses and Dissertations. Paper 3469.

https://doi.org/10.18297/etd/3469

This Master's Thesis is brought to you for free and open access by ThinkIR: The University of Louisville's Institutional Repository. It has been accepted for inclusion in Electronic Theses and Dissertations by an authorized administrator of ThinkIR: The University of Louisville's Institutional Repository. This title appears here courtesy of the author, who has retained all other copyrights. For more information, please contact thinkir@louisville.edu. 


\title{
HOW NONDISCRIMINATION TAKES ROOT: AN EXAMINATION OF METHODS TO IMPLEMENT STATEWIDE NONDISCRIMINATION LEGISLATION IN KENTUCKY
}

\author{
By \\ Blake Nona Gould \\ B.S., University of Louisville, 2016

\begin{abstract}
A Thesis
Submitted to the Faculty of the

College of Arts and Sciences of the University of Louisville

in partial fulfillment of the Requirements

for the Degree of
\end{abstract}

Master of Public Administration

Department of Urban and Public Affairs

University of Louisville, Kentucky

May 2020 



\title{
HOW NONDISCRIMINATION TAKES ROOT: AN EXAMINATION OF METHODS TO IMPLEMENT STATEWIDE NONDISCRIMINATION LEGISLATION IN KENTUCKY
}

\author{
By \\ Blake Nona Gould \\ B.S., University of Louisville, 2016
}

A Thesis Approved on

April 29, 2020

by the following Thesis Committee:

\begin{tabular}{c}
\hline Dr. Lindsay Evans \\
\hline Dr. Janet Kelly \\
\hline Dr. Aaron Rollins
\end{tabular}




\section{ABSTRACT \\ HOW NONDISCRIMINATION TAKES ROOT: AN EXAMINATION OF METHODS TO IMPLEMENT STATEWIDE NONDISCRIMINATION \\ LEGISLATION IN KENTUCKY}

Blake N. Gould

April 29, 2020

This research examined the numerous fairness ordinances in Kentucky's cities for repeated trends, patterns, and practices in their language. Through the use of a cumulative case study, cases were selected from the ordinances as well as state and federal law, judicial actions, and other relevant factors from within the state. Each of the ordinances were examined for generalizability and their ability to be applied to a single, unified state nondiscrimination law that conforms with existing state and federal law. It was found that significant similarities exist between the various ordinances, though discrepancies would also need to be addressed. In the formulation of a statewide law, the administrative measures taken by the municipalities provide the best direction to state administrators. This research will prove useful and instructive for state officials in Kentucky hoping to model a nondiscrimination law off of the state's cities' efforts from the past two decades. 


\section{TABLE OF CONTENTS}

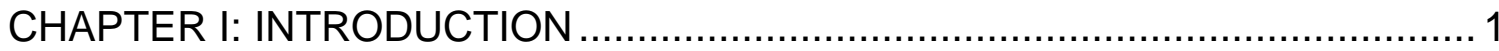

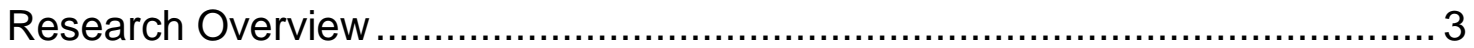

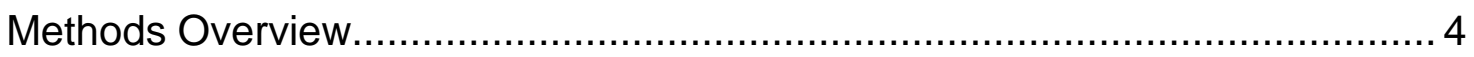

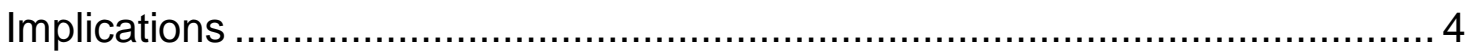

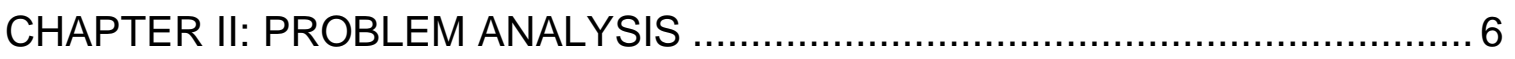

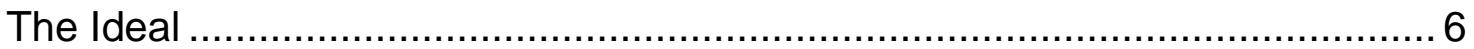

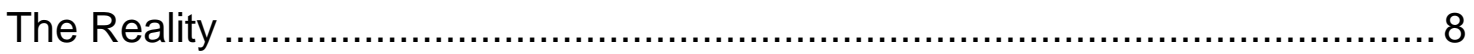

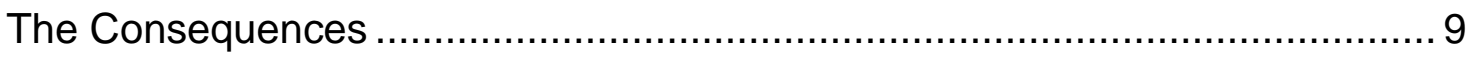

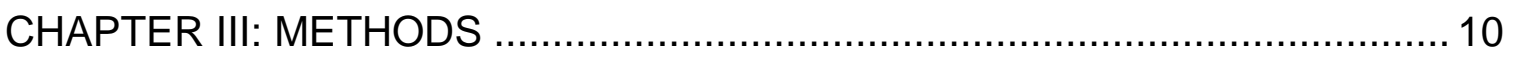

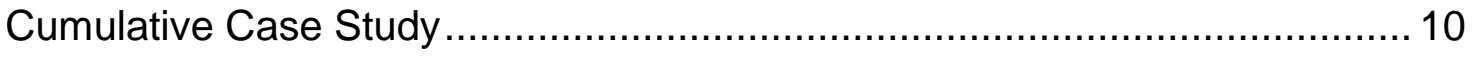

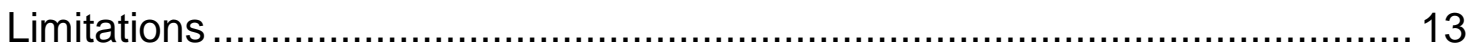

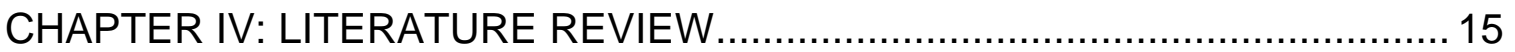

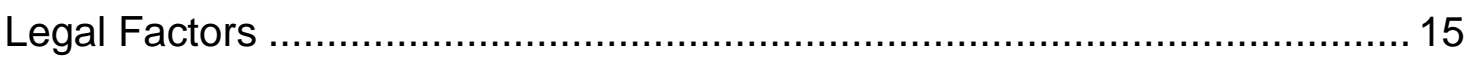

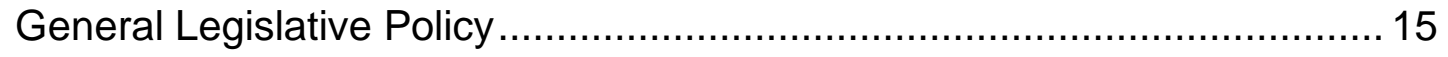

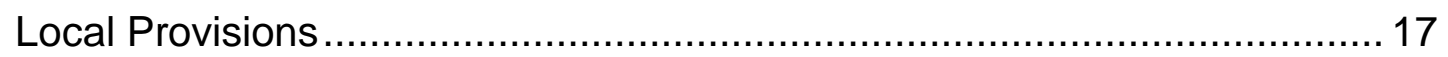


Louisville

Lexington 18

Henderson's Failed Ordinance 19

Covington 20

Small Town Action Defines the 2010's 20

Preemptive Legislation in Kentucky 24

Judicial Action 27

Sociocultural Factors 29

The Prevalence of Religion 29

Understanding the Lack of Diversity in Rural Areas Reveals a Need for a Statewide Law. 32

Examining Henderson. 33

Administrative Factors 34

Louisville and Lexington-Fayette's Approach. 35

Administrative Steps from Across the State..... 36

Statewide Administrative Orders. 40

The Reality of Statewide Fairness in Kentucky 40

CHAPTER V: ANALYSIS: DESIGNING A KENTUCKY LEGISLATION 43

The Benefits of Uniformity 43 


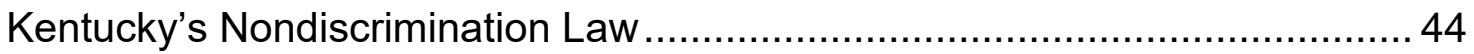

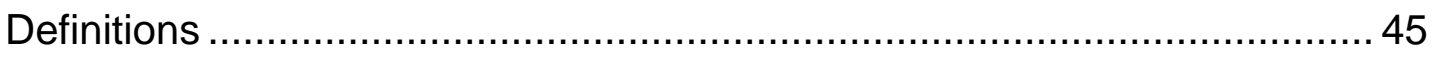

Empowering the Kentucky Commission on Human Rights ......................... 47

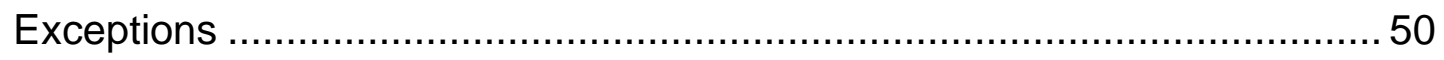

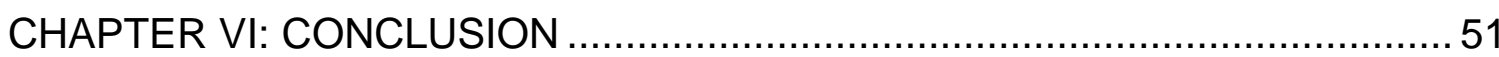

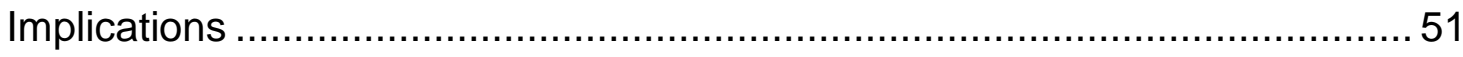

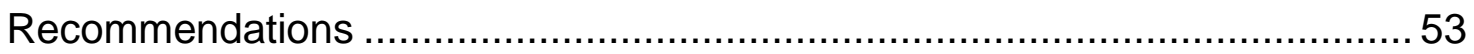

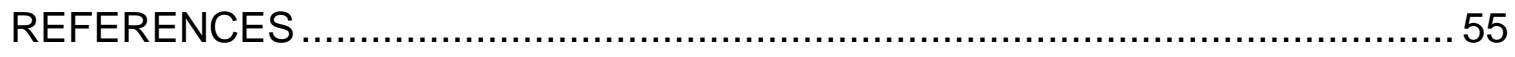

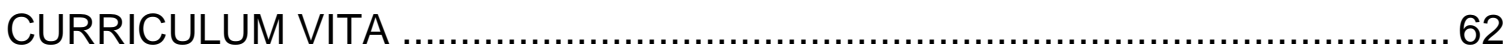




\section{LIST OF TABLES}

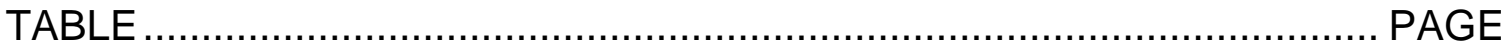

1. Comparing the Protections and Definitions of Kentucky Fairness Ordinances

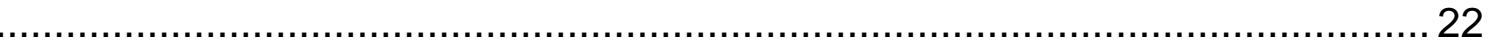

2. Administrative Remedies Undertaken by Various Ordinances..................39 


\section{CHAPTER I \\ INTRODUCTION}

The storied development of civil rights in the United States is a well-known history. One needs only to walk down any downtown street to see the effects of a century and a half of progress on this front and see the advances that have been made in civil rights and equity. These years have been full of legal, judicial, and cultural developments have made it so, at least legally, there is little sanctioned discrimination. However, there is a strong body of research that discusses how systematic discrimination is still embedded in the various aspects of American life (Bertrand and Mullainathan 2004, Johnson and Gosselin 2018). This research focuses on the significant legal developments that have formally recognized the various diversities that exist in the United States and the provisions of equal protections under the law.

Whether or not certain groups of citizens possess specific protections is dependent on if relevant codified law enumerates that group. A close read of pertinent legislation reveals distinct patterns. The Civil Rights Act of 1964 outlines protections based on an "individual's race, color, religion, sex, or national origin" (EEOC Title VII, 1964). Modern civil rights laws outline specifically to whom protections are extended. While this creates a number of individuals who can lay claim to these protections, it also provides an opportunity for discrimination on factors not specifically enumerated. For example, as it was 
written, the Civil Rights Act of 1964 does not protect citizens based on sexual orientation (EEOC, Title VII, 1964). Accordingly, discrimination against gay, lesbian, and bisexual persons can be argued as legal if the decision is made strictly based on the wording of the 1964 legislation (EEOC Title VII, 1964).

It would not be until 2015 with the Equal Employment Opportunity Commission's Title VII ruling, when sex discrimination protections were extended to include sexual orientation (EEOC, 2015). Though this did not include protections specifically protecting the rights of LGBTQ+ persons, this decision has helped advance equal protection issues further. This reading of the law creates an opening, though, for more concentrated, local approaches to nondiscrimination. The strategy for proponents of intersectional discrimination protections, or protections that are written with the awareness of the overlapping nature of historically discriminated groups, should be to pass legislation that strictly protects LGBTQ+ people and their rights.

It is the goal of more modern nondiscrimination laws to formally incorporate protections for additional groups of people. This research will examine local ordinances in Kentucky that include LGBTQ+ people as a protected group by making illegal any discrimination on the bases of sexual orientation (i.e. gay, bisexual, pansexual) or gender identity (i.e. transgender, nonbinary, agender) and determine what factors contribute to political salience for these laws, as well as what future nondiscrimination movements can learn from the past. Following this analysis, this research will make the case for a 
statewide nondiscrimination law in Kentucky by synthesizing the common themes found among local laws in the Commonwealth.

\section{Research Overview}

This research will explore relevant examples of civil rights legislation and will examine areas where additional progress could be made. This study examines 'fairness ordinances' - more broadly known as nondiscrimination laws. Fairness ordinances seek to expand the protections against discrimination afforded by existing civil rights legislation specifically to individuals along the LGBTQ+ spectrum within the jurisdiction of a city or county. The Fairness Campaign, a Louisville-based 501(c)(4) organization, is highly responsible for the advocacy and spread of fairness ordinances in Kentucky (Fairness Campaign 2020). The goal of the Fairness Campaign is to promote "comprehensive civil rights legislation prohibiting discrimination on the basis of sexual orientation and gender identity and to dismantle systemic racism" (Fairness Campaign 2020).

This research will examine the disparities between nondiscrimination legislation and protections in urban areas and compare these to rural areas. One of the major hurdles of designing a statewide law is making it appropriate for all citizens, not just those in more populous, urban areas. This research will begin by highlighting specific sociocultural, legal, and administrative differences common between urban and rural areas and will explore variables relevant to developing local, nondiscrimination legislation. Second, this research will examine several significant successes of nondiscrimination laws in rural Kentucky, compare them to urban areas, and analyze these for patterns that can 
be generalized. Finally, this research will outline a series of recommendations for public officials and administrators seeking to implement a statewide law. It is the goal of this research to provide a guide for future action on the part of state administrators and legislators.

\section{Methods Overview}

The research will follow the format of a cumulative case study. The goal of this case study method is to provide generalizable results based on the examination of specific cases. An extensive literature review will support the main body of this research as it seeks to exemplify patterns in nondiscrimination successes and failures, along with a critical examination of the sociocultural, legal, and administrative influences at hand. The cumulation will first outline common patterns across the cases, including specific provisions of the laws and how they were implemented, and then identify key methods administrators may take to enact a successful fairness ordinance.

Implications

Advocates for LGBTQ+ nondiscrimination are responding to the nation's current wave of improved legal protections (Movement Advancement Project 2020). In Kentucky alone, as of the end of 2019, fourteen municipalities had enacted fairness ordinances in the past twenty years (Fairness Campaign 2019). While fairness ordinances have been spread these last few decades, it was not until 2015 with the Supreme Court decision in Obergefell $v$. Hodges that allowed same-sex marriage that it became clear that national level change be possible. This research contributes to the literature by highlighting strategies and 
approaches administrators may pursue to further contribute to the development of these laws at both the local and the state levels. 


\section{CHAPTER II \\ PROBLEM ANALYSIS}

The Ideal

The United States, as a progressive, developed nation, has an expressed goal of providing its citizens with livelihoods based on pure equality. As outlined in its founding documents, all citizens should be viewed as equal under the law and should therefore be treated as such by the nation's institutions and by their fellow citizens. In today's diverse America, that would come in the form of respect for each individual's unique racial, ethnic, religious, and economic backgrounds, along with a myriad of other descriptors that we all ascribe to.

Equality was, of course, not the de facto situation at this country's founding. Many momentous occasions in history have sought to rectify this, including the Reconstruction Era Amendments, universal suffrage, and the civil rights laws. As more and more diverse peoples are granted strict protections by judicial, constitutional, and legislative actions, the United States draws closer to its initial goals of equality.

The ideal in the United States is more akin to social equity, rather than equality. As described by Wooldridge and Gooden, this concept as an "epic" that has been constructed over time "through the values and principles of the continuous search for social justice and the improvement of our social fabric" 
(Wooldridge and Gooden 2006, p. 222). The appeal of such an approach to social policy is that it is an evolving reference point, showing the prescience of its formulators to the continuously changing fabric that is the citizenry of the United States and their respective social values. The power of social equity lies in the necessity of John Rawls' "veil of ignorance" behind which policymakers can determine the most equitable action (Wooldridge and Gooden 2006, p. 223). As expanded civil rights legislation is held to be representative of equitable policy (Wooldridge and Gooden 2006, p. 224), expanding these same rights to LGBTQ+ people is a natural evolution of social equity.

The fairness ordinances seek to expand civil rights protections to people that identify as LGBTQ+. These include protections from discrimination in employment, housing, and public accommodations. The same protections already exist in the United States, but just for other factors including race and age (EEOC Title VII 1964). Fairness ordinances seek to expand this umbrella of protection to another group that needs these protections.

So long as specific groups of United States citizens are excluded from such foundational legislation, social equity is clearly not being served and the baseline dreams of equality the nation was founded on are being failed as well. In key moments in United States history, administrators and lawmakers recognized significant injustices built into the system. Reforms typically followed which ultimately resulted in such momentous actions such as the Civil Rights Act. More reforms are now necessary to ensure protections for LGBTQ+ citizens. 
The Reality

There is still much work to be done in regards to achieving these goals, however. Certain minorities, including the LGBTQ+ population, are reliant on equitable laws to specifically protect their rights against various forms of discrimination because discrimination is still a factor in American life. Without explicit legal protections, LGBTQ+ people are more vulnerable to discrimination (Singh and Durso, 2017). Even LGBTQ+ citizens who live in jurisdictions with nondiscrimination ordinances have an increased likelihood of being subjected to mistreatment based on the fact that they are LGBTQ+. In Louisville, which is one of the early pioneers of Kentucky nondiscrimination law, hate crimes are still recorded against LGBTQ+ people (Bindley, 2012). Until all Americans can enjoy the same equal protections under the law and until those protections are sufficient to discourage all forms of discrimination, there is still work to be done on increasing social equity in the United States.

To combat this inequity, cities and other smaller jurisdictions have begun to implement nondiscrimination ordinances to address deficiencies in federal and state civil rights laws. While this shows promising progress, it thus creates a patchwork in the United States where, based on your location, citizens can enjoy protections that should be automatically afforded to them by federal law and others cannot. Rural LGBTQ+ citizens are unfairly treated by this reality as it is more likely for citizens of large, metropolitan areas to be covered by nondiscrimination laws (MAP 2019, p. 63). In Kentucky, Lexington and Louisville are the only two cities with 100,000+ people in Kentucky (World Population Review, 2019) and they were 
the first two to pass Fairness Ordinances, both in 1999 (Fairness Campaign). Since then, of the fourteen Kentucky cities to have passed fairness ordinances (Fairness Campaign), five of them have fewer than 10,000 (World Population Review, 2019) with the smallest, Vicco, having around 300 citizens (MAP 2019, p. 63). Administrators in Kentucky and across the country are now turning their focus on smaller and more rural cities where, at least traditionally, support for LGBTQ citizens may be harder to find.

\section{The Consequences}

This research hopes to support current and future administrative leaders in the United States to undertake nondiscrimination measures that have the best chances of succeeding. As can be seen in the mission statements of progressive organizations like the Fairness Campaign, a grassroots approach to combatting inequality will sow the seeds of change in American society and create a climate in which all Americans can safely enjoy equal rights (Fairness Campaign 2019). However, Kentucky is at a tipping point where more and more citizens are living in jurisdictions with fairness ordinances. There will come a time, not too far from now, when the only way to continue to expand civil rights protections will be to unify the fairness ordinances into a statewide law. This study provides a cumulative review of the literature regarding some notable instances of fairness ordinances in Kentucky, both in rural and urban settings, and highlights effective strategies used in those situations. By compiling this information, the goal of this research is to align Kentucky's ideal for an evolved approach to social equity with the modern reality. 


\section{CHAPTER III}

\section{METHODS}

\section{Cumulative Case Study}

This research is a cumulative case study. As outlined by Hayes et al. (2015), the advantages of a case study format is it allows a researcher to "provide a greater generalization of the results of multiple case studies that have been conducted at different times and locations" (Hayes et al. p. 18, 2015). Due to the sheer number of local ordinances that can be examined and the variety of localities where they occur, it is advantageous to use this approach to compile that data into a manageable collection of information. This type of study makes it possible to take information from a much larger amount of data without the need to create individual case studies for each phenomenon (Hayes et al. 2015, p. 18). In addition, this format has significant advantages when taking a retrospective view of the subject (GAO 1990, p. 57).

The application of this format to policy issues was attested to by the Government Accountability Office ("GAO") in 1990. At that time, even though the GAO itself had not undertaken such a study, it recognized that its own reports had been "used with good results" by other organizations (GAO 1990, p. 58). These studies had covered policy-related topics including effectiveness of educational 
programs and the failures of management in administrative bodies (GAO 1990, p. $58)$.

The GAO recognized potential fallacies within the cumulative case study. First, as the format involves selection of cases by the author(s), there is a substantial risk of bias (GAO 1990, p. 60). In this research, every fairness ordinance with publically available text, both active and failed, is examined, thus mitigating this risk. The GAO also recognizes risks relating to the quality of the data being collected (GAO 1990, p. 61), though this is a hurdle for almost any form of study. In this study, the vast majority of primary data collected comes directly from local ordinances, state and federal law, and other government documents, all of which can typically be relied upon for veracity.

The case, or herein cases, under study are phenomena, rather than a single incident or person. As such, this study does not consist of direct interviews or data collection from specific localities. This case study instead consists of "an in-depth analysis of a cause and effect that is grounded in an interactive relationship between people and their environment in some way" (USC Libraries, 2019). In this study, this relationship is an examination of the construction of a nondiscrimination law and the sociocultural, legal, and administrative factors of a given community.

The cumulative format is characterized by four main design components: site selection, case sample selection, cumulate findings, and reporting the results (Hayes et al. p. 18, 2015). Site selection and case sample selection, in this study, will be concurrent. Selection will take the format of examining Kentucky's history of passing local fairness ordinances and what common factors are involved in both 
their text and context. This analysis will exhibit a degree of focus on the sociocultural, legal, and administrative forces at work in devising a nondiscrimination ordinance, as well as the forces that may oppose such a measure.

For this research, the legal factors involve not only the history of the ordinance in question but also the legal and constitutional parameters of the respective state. Sociocultural factors will include examining the impact of religion, diversity rates in urban and rural communities, and other such trends. Administratively, this research will examine where the impetus for fairness ordinances originate and what administrative bodies are involved with the passing and enforcement of such an ordinance.

To cumulate findings, this research will examine what factors contribute to a successful or unsuccessful nondiscrimination ordinance, both in rural and urban settings. As noted earlier, these factors will take three overarching forms: legal, sociocultural, and administrative. These findings will be reported in the literature review to follow.

Legal factors of these laws include the wording of the laws themselves and analysis of what characteristics contribute to a successful ordinance. Also included here is a review of relevant historical statutory law and its impact upon modern law. Sociocultural factors that are relevant to fairness ordinances include allowances made for religious freedom, variance between rural and urban settings, and general effectiveness of the laws, as measured by difficulties felt in either passing or maintaining the laws. Finally, administrative factors include tools of 
enforcement and the mechanisms of law that enable the effective passage of such laws.

Taking this wide-angle approach to collecting data is conducive to the purpose of a cumulative case study. The strength of this method lies in its generalizability, something that is clearly helpful in aggregating disparate laws (Hayes et al. 2015, p. 18). In developing a law that is appropriate on a statewide setting, it is necessary to examine the multifaceted nature of the entire populace. Kentucky presents a particularly effective example of this as one, it features numerous fairness ordinances already in effect and, two, the ordinances belong to a diverse set of municipalities, ranging from truly metropolitan to small and rural.

Finally, reporting the results will occur within the analysis of this paper. This analysis will seek patterns that may be followed from each individual case and report them in a method that can prove instructive for political and administrative bodies. It will also be important to report a lack of measurable patterns, as that alone can be highly instructive.

\section{Limitations}

The cumulative case study is not without its limitations. According to Hayes et al. (2015, p. 19), there are three main 'pitfalls':

1. The researcher is responsible for selecting and excluding specific cases from the study, thus arbitrarily injecting a degree of bias into the study;

2. As the 'research' has already been conducted by the studies involved in the chosen cases, and those studies were carried out by various parties, there may be a variation in the quality of research between those cases; and 
3. Changes in context over time at the selected sites may affect the results of the research (Hayes et al. 2015, p. 19).

These limitations are offset in this research by a heavy reliance on litigated matters of policy. The local policies reviewed are exhaustive of all of Kentucky's fairness ordinances, successful and failed, until the end of 2019. These primary resources are biased only insofar as they reveal the preferences of the jurisdictions that they come from, a factor that is relevant to this research.

The third limitation is difficult to account for, as any source, given enough time, may become outdated. In this research, one locality is examined for the differences encountered over two decade from a failed ordinance to an eventual successful on. Similar to the relevancy of the differences between various ordinances, this discrepancy over time is also relevant as it is a clear case of changing political interest in the city. 
CHAPTER IV

\section{LITERATURE REVIEW}

In the section to follow, a variety of recent cases of fairness ordinances will be examined for their specific sociocultural, legal, and administrative features that were at play in each. Additionally, foundational legal and judicial documents that have a bearing on civil rights will be examined as they provide the bedrock upon which all fairness ordinances seek to protect American citizens. The goal of this section is to accumulate examples of common factors seen in efforts to pass nondiscrimination legislation.

\section{Legal Factors}

\section{General Legislative Policy}

There are no federal laws that explicitly prohibit discrimination against LGBTQ+ people in the areas of employment, housing, public accommodations, and others (Movement Advancement Project 2019, p. 54). These specific protections do exist for Americans in general thanks to the 1964 Civil Rights Act, but only on the basis of categories including religion, race, and gender assigned at birth (EEOC Title VII 1964). Because the original law does not specifically enumerate sexual orientation or gender identity as protected groups, one cannot bring legal action against offenders if discrimination occurred because, for 
example, they found out you were gay. The Civil Rights Act was expanded upon by the Equal Employment Opportunity Commission in 2015 when the Commission decided that Title VII's sex discrimination protections actually implied sexual orientation protections as well (EEOC 2015).

The EEOC was not the only group to arbitrarily expand the purview of federal legislation. Some jurisdictions have chosen to interpret federal laws to include protections on the basis of sexual and gender identity. Five federal court districts have made the interpretation that federal sex discrimination laws also prohibit gender identity discrimination, these being the $1^{\text {st }}, 6^{\text {th }}, 7^{\text {th }}, 9^{\text {th }}$, and $11^{\text {th }}$ districts, while the $2^{\text {nd }}$ and the $7^{\text {th }}$ have extended the same protection on account of sexual orientation (MAP 2019, p. 55). The remaining federal districts, however, have either not ruled on these issues or have decided that these factors are not protected (MAP 2019, p. 55).

Until the Supreme Court takes up a case dealing with these issues, public officials have to contend with the current reality where federal laws are not being enforced equally across the nation. The South and the Midwest are less likely to have formal protections than other regions (MAP 2019, p. 59). LGBTQ+ people living these areas, by choice or otherwise, are far more likely to be subjected to laws that enable discrimination, including religious exemption laws and laws criminalizing perceived or potential HIV exposure (MAP 2019, p. 59-60). A uniform anti-discrimination law is necessary "to ensuring that everyone in the U.S. can experience the same rights and protections in every part of the country" (MAP 2019, p. 54). 


\section{Local Provisions}

To address this deficit stemming from the 1964 law, Kentuckians have seen local and state measures like fairness ordinances that seek to extend protections within their own jurisdictions. It is prudent to take a closer look at these laws, as their causes are the main focus of this research. Examination of these laws will take the form of legislative stories, wherein the laws themselves are granted context by the actions of individuals and communities involves in their passage.

\section{Louisville}

The Louisville, Kentucky fairness ordinance, passed in 1999, made illegal any discrimination on the bases of sexual orientation and gender identity in employment, housing, and public accommodations (Bennett 2011, p. 18). Sexual orientation was defined as "an individual's actual or imputed heterosexuality, homosexuality, or bisexuality," and gender identity was defined as "manifesting an identity not traditionally associated with one's biological maleness or femaleness" (Bennett 2011, p. 18).

The ordinance was originally adopted by Jefferson County's Fiscal Court, its chief legislative body. The four members voted three to one in favor of the measure (Bennett 2011, p. 18). At this time, Jefferson County and Louisville were not a unified government and the provisions within the legislation placed "the county ahead of the city on gay rights" (Bennett 2011, p. 18). At this time, the city already had a nondiscrimination ordinance regarding employment protections. The 1999 ordinance expanded protections, however, toward housing and public accommodations in the county (Bennett 2011, p. 18-19). 
Once the city and the county became a unified government in 2003, the new legislative body, the Metro Council, would have to re-examine the law or it would lapse in 2007 (Bennett 2011, p. 24-25). The reborn conflict brought about significant opposition, leading to no small amount of community activism (Bennett 2011, p. 25). Ultimately, the Council reenacted the broader county ordinance in a vote of nineteen to six (Bennett 2011, p. 28).

\section{Lexington}

Lexington, the next largest metropolitan area of Kentucky, also passed a fairness ordinance in 1999. It expanded civil rights protections on account of sexual orientation and gender identity, with a word-for-word identical definition of sexual orientation. Its gender identity definition, however, added a significant portion, reading "having a gender identity as a result of a sex change surgery, or manifesting for reasons other than dress, an identity not traditionally associated with one's biological maleness or femaleness" (Bennett 2011, p. 66). The specific designation of a sex change surgery is interesting, though it does not necessarily take away from the effect of the definition. The definition's expansion is largely irrelevant as, in the following clause, "manifesting" would implicitly cover such things as a sexual confirmation surgery, thus making the inclusion of that term unnecessary.

The legislative history of Lexington-Fayette County's fairness ordinance was characterized by numerous amendments. Though it ultimately passed with a vote of 12 to 3 (Bennett 2011, p. 66), those three 'no' votes were staunchly opposed to the measure. For the most part, they offered pragmatic and 
administrative challenges to the law, claiming such things a need for a 'maximum fine' and that it would be legally difficult to manage (Bennett 2011, p. 65). Ultimately, a series of amendments made passage attainable, as provisions for religious exemptions caused council members to switch sides in favor (Bennett 2011, p. 66).

\section{Henderson's Failed Ordinance}

The public movement for a fairness ordinance in Henderson began in May of 1999, a little more than a month before Lexington's law was formally considered (Bennett 2011, p. 69). They were spurred by the outspoken antagonism displayed by Henderson Commissioner Robby Mills. Mills made an effort to bring the local press into negotiations on the fairness ordinance, hoping to alert citizens who would oppose the ordinance (Bennett 2011, p. 69). Mills and fellow commissioner Russell Sights joined together in their opposition and strove to make the process as transparent and public as possible (Bennett 2011, p. 69-70), something that fairness advocates recognized would jeopardize the ordinance (Bennett 2011, p. 69). Its eventual passage was notable in that it contradicted the majority voice of Henderson's constituents who opposed the law (Bennett 2011, p. 85).

The ordinance contained protections for sexual orientation, but not for gender identity, showing a difference from its contemporaries. Another notable difference lay in the language itself, which was far weaker and more conservative than its contemporaries (Bennett 2011, p. 68). This was done by supporters of the law in order to, hopefully, bring on board more of its opponents. This backfired, resulting in significantly weakened penalties and enforcement provisions. 
Henderson's ordinance would end up being repealed eighteen months later after stiff backlash from a vocal and conservative religious majority (Bennett 2011, p. 120). The issue would be revisited twenty years later in 2019 when Henderson became the eleventh Kentucky city to adopt a full fairness ordinance that included protections for gender identity (White 2019).

\section{Covington}

In 2003, Covington passed the only fairness ordinance of the first decade of the twenty-first century. This ordinance mirrored many of the aspects of Lexington's fairness ordinance (Bennett 2011, p. 174). Not only did Covington incorporate sexual orientation and gender identity protections, but it protected citizens in housing and public accommodations, something that, at this point, Louisville had not enacted (Bennett 2011, p. 174). Covington's definition of 'employer' would represent a more conservative approach, however. Covington defines an 'employer' as having fifteen or more employees, while Lexington's definition defines it as only one or more employee (Wales 2017, p. 31).

\section{Small Town Action Defines the 2010's}

Following Covington's 2003 fairness ordinance, there was a ten-year gap in the passing of Kentucky fairness. Breaking this interim, the small city of Vicco passed its own fairness ordinance in 2013. As the record smallest United States town with such a law, its 334 residents (Wales 2017, p. 28) gained national recognition as a sort of anomaly. The law's passage opposes the conventional wisdom that rural Americans are hostile to more 'liberal' viewpoints. Contrary to 
this, rural America is estimated to have 3 to 5 percent LGBT citizens, which is consistant with the 4.5 percent national average (MAP 2019, p. iii). Remarkably, the mayor of the town, Johnny Cummings is a gay man (Hunter, 2013), and he has remained mayor ever since the vote.

The small town's actions appeared to open the floodgates. After Vicco, there were four other fairness ordinances passed in 2013: Frankfort, Morehead, Danville, and Midway. After Frankfort's, a quarter of Kentucky's residents were now protected by LGBTQ+ anti-discrimination measures (Kocher 2013). Expansions of fairness ordinances would continue throughout the decade, and by early 2019, six more cities would pass these laws: Paducah, Maysville, Henderson, Dayton, Georgetown, and Versailles.

All fourteen of Kentucky's fairness ordinances through 2019 are largely uniform in design. Many of them possess identical language in significant portions of the legislation, particularly in specifying that sexual orientation and gender identity are being protected. The fact that both of these factors are uniformly accounted for is actually quite remarkable. Across the United States, only 22.6 percent of municipalities that forbid employment discrimination on account on sexual orientation do the same for gender identity. In Kentucky, 100 percent of municipalities that prohibit employment discrimination on account of sexual orientation also do so for gender identity (Wales 2017, p. 31).

The primary disparity seen amongst Kentucky's fairness ordinances lies in the definition of what exactly constitutes an 'employer'. The most expansive definition of employer in the state is found in Lexington, where an employer is "any 
individual, firm, corporation, partnership, or agency that employs one employee" (Wales 2017, p. 32). Starting in 2003, this definition becomes its strictest. Covington, Vicco, Frankfort, Morehead, and Danville all define an employer as having fifteen or more employees at a given time (Wales 2017, p. 32). After this time, the definition varies, with most requiring eight employees (Paducah 2018, Henderson 2019, Georgetown 2019), though the fifteen employee requirement reappears in Dayton (Dayton 2019).

In examining these ordinances (Table 1), we see a pattern. Localities generally follow this pattern for expanding civil rights protections within their cities. For a summary of the similarities between the various ordinances, see Table 1. Henderson's eventual second fairness ordinance shows how the dialogue has advanced in the two decades since their first ordinance, even in locations that previously showed stark opposition to these laws. For example in 2004, 75 percent of Kentuckians supported a constitutional amendment to define marriage as between a man and a woman (Wales 2017, p. 28). Now that it has been more formally explored, when fairness ordinances are discussed, it is this general language seen across Kentucky that is being referred to; specific protections in public and private affairs on account of sexual orientation and gender identity.

\section{Table 1}

Comparing the Protections and Definitions of Kentucky Fairness Ordinances

\begin{tabular}{|c|l|l|l|}
\hline Year & \multicolumn{1}{|c|}{ Locality } & Key Considerations & \multicolumn{1}{c|}{$\begin{array}{c}\text { Definition of } \\
\text { Employer }\end{array}$} \\
\hline 1999 & $\begin{array}{l}\text { Louisville (city then } \\
\text { metro }\end{array}$ & $\begin{array}{l}\text { Prevented discrimination } \\
\text { based on sexuality or }\end{array}$ & $\begin{array}{l}\text { Any organization that } \\
\text { employs two or more }\end{array}$ \\
\hline
\end{tabular}




\begin{tabular}{|c|c|c|c|}
\hline & & $\begin{array}{l}\text { gender identity in work, } \\
\text { housing, and public } \\
\text { accommodation. }\end{array}$ & $\begin{array}{l}\text { employees for four or } \\
\text { more weeks in a } \\
\text { calendar year }\end{array}$ \\
\hline 1999 & $\begin{array}{l}\text { Lexington-Fayette } \\
\text { County }\end{array}$ & $\begin{array}{l}\text { Prevented discrimination } \\
\text { based on sexuality or } \\
\text { gender identity in work, } \\
\text { housing, and public } \\
\text { accommodation. }\end{array}$ & $\begin{array}{l}\text { Any individual, firm, } \\
\text { corporation, partnership, } \\
\text { or agency that employs } \\
\text { one employee }\end{array}$ \\
\hline Year & Locality & Key Considerations & $\begin{array}{l}\text { Definition of } \\
\text { Employer }\end{array}$ \\
\hline 2003 & Covington & $\begin{array}{l}\text { Prevented discrimination } \\
\text { based on sexuality or } \\
\text { gender identity in work, } \\
\text { housing, and public } \\
\text { accommodation. }\end{array}$ & $\begin{array}{l}\text { Any person that employs } \\
\text { fifteen or more } \\
\text { employees for four or } \\
\text { more weeks in a } \\
\text { calendar year }\end{array}$ \\
\hline 2013 & Vicco & $\begin{array}{l}\text { Prevented discrimination } \\
\text { based on sexuality or } \\
\text { gender identity in work, } \\
\text { housing, and public } \\
\text { accommodation. }\end{array}$ & $\begin{array}{l}\text { Any person that employs } \\
\text { fifteen or more } \\
\text { employees for four or } \\
\text { more weeks in a } \\
\text { calendar year }\end{array}$ \\
\hline 2013 & Frankfort & $\begin{array}{l}\text { Prevented discrimination } \\
\text { based on sexuality or } \\
\text { gender identity in work, } \\
\text { housing, and public } \\
\text { accommodation. }\end{array}$ & $\begin{array}{l}\text { Any person that employs } \\
\text { fifteen or more } \\
\text { employees for four or } \\
\text { more weeks in a } \\
\text { calendar year }\end{array}$ \\
\hline 2013 & Morehead & $\begin{array}{l}\text { Prevented discrimination } \\
\text { based on sexuality or } \\
\text { gender identity in work, } \\
\text { housing, and public } \\
\text { accommodation. }\end{array}$ & $\begin{array}{l}\text { Any person that employs } \\
\text { fifteen or more } \\
\text { employees for four or } \\
\text { more weeks in a } \\
\text { calendar year }\end{array}$ \\
\hline 2013 & Danville & $\begin{array}{l}\text { Prevented discrimination } \\
\text { based on sexuality or } \\
\text { gender identity in work, } \\
\text { housing, and public } \\
\text { accommodation. }\end{array}$ & $\begin{array}{l}\text { Any person that employs } \\
\text { fifteen or more } \\
\text { employees for four or } \\
\text { more weeks in a } \\
\text { calendar year }\end{array}$ \\
\hline 2013 & Midway & $\begin{array}{l}\text { Prevented discrimination } \\
\text { based on sexuality or } \\
\text { gender identity in work, } \\
\text { housing, and public } \\
\text { accommodation. }\end{array}$ & $\begin{array}{l}\text { Any person that employs } \\
\text { fifteen or more } \\
\text { employees for four or } \\
\text { more weeks in a } \\
\text { calendar year }\end{array}$ \\
\hline 2018 & Paducah & $\begin{array}{l}\text { Prevented discrimination } \\
\text { based on sexuality or } \\
\text { gender identity in work, } \\
\text { housing, and public } \\
\text { accommodation. }\end{array}$ & $\begin{array}{l}\text { A person who has eight } \\
\text { or more employees } \\
\text { within the state in each } \\
\text { of } 20 \text { or more calendar } \\
\text { weeks in the current or } \\
\text { preceding calendar year } \\
\text { and an agent of such a } \\
\text { person }\end{array}$ \\
\hline 2018 & Maysville & $\begin{array}{l}\text { Prevented discrimination } \\
\text { based on sexuality or } \\
\text { gender identity in work, } \\
\text { housing, and public } \\
\text { accommodation. }\end{array}$ & Undefined \\
\hline
\end{tabular}




\begin{tabular}{|l|l|l|l|}
\hline Year & Locality & Key Considerations & $\begin{array}{l}\text { Definition of } \\
\text { Employer }\end{array}$ \\
\hline 2019 & Henderson & $\begin{array}{l}\text { Prevented discrimination } \\
\text { based on sexuality or } \\
\text { gender identity in work, } \\
\text { housing, and public } \\
\text { accommodation. }\end{array}$ & $\begin{array}{l}\text { A person who has eight } \\
\text { or more employees } \\
\text { within the state in each } \\
\text { of 20 or more calendar } \\
\text { weeks in the current or } \\
\text { preceding calendar year } \\
\text { and an agent of such a } \\
\text { person }\end{array}$ \\
\hline 2019 & Dayton & $\begin{array}{l}\text { Prevented discrimination } \\
\text { based on sexuality or } \\
\text { gender identity in work, } \\
\text { housing, and public } \\
\text { accommodation. }\end{array}$ & $\begin{array}{l}\text { A person engaged in an } \\
\text { industry affecting } \\
\text { commerce who has } \\
\text { fifteen or more } \\
\text { employees for each } \\
\text { working day in each of } \\
\text { twenty or more calendar } \\
\text { weeks in the current or } \\
\text { preceding calendar year }\end{array}$ \\
\hline 2019 & Georgetown & $\begin{array}{l}\text { Prevented discrimination } \\
\text { based on sexuality or } \\
\text { gender identity in work, } \\
\text { housing, and public } \\
\text { accommodation. }\end{array}$ & $\begin{array}{l}\text { A person who has eight } \\
\text { or more employees } \\
\text { within the city in each of } \\
\text { twenty or more calendar } \\
\text { weeks in the current or } \\
\text { preceding calendar year } \\
\text { and any agent of such a } \\
\text { person }\end{array}$ \\
\hline
\end{tabular}

Wales 2017, Ordinances of Paducah (2018), Maysville (2018), Henderson (2019), Dayton (2019), and Georgetown (2019).

\section{Preemptive Legislation in Kentucky}

There does exist some specific legislation in Kentucky that stands in opposition to attempts to expand LGBTQ+ rights. Called 'preemption laws', these are not a novel concept in the legislation in the United States. Commonly considered to be governed by the Supremacy Clause in Article VI of the United States Constitution (National Archives 2019), preemptive legislation is drafted by a legal authority in order to control what a lower level of legal authority may or may not allow. Often overlooked, however, is this same relationship between states and 
the localities contained within them. States have a similar degree of authority over municipalities that the United States government has over the states themselves.

As soon as municipalities began to pursue LGBTQ+ rights activism on their own, the generally more conservative statewide governments took notice. Seeking to stop these expansions of rights, state governments began to pass preemptive measures as early as 1992 in Colorado, where a ballot initiative strictly prohibited local nondiscrimination laws. The ballot stood for four years and was ultimately overturned in the U.S. Supreme Court (Riverstone-Newell 2017, p. 416). Today, three states have active preemptive laws on the books that bar local nondiscrimination laws: Arkansas, Tennessee, and North Carolina (MAP Equality Maps 2019).

Kentucky does not have one such law barring local nondiscrimination matters. It does however have multiple examples of legislation that have themselves been preempted by federal law. In 2004, Kentucky passed a law banning both same-sex marriage and civil unions. This spent more than a decade as the dominant law on this issue in Kentucky (Equaldex 2020). In 2015, the Supreme Court decided on Obergefell v. Hodges, thus preempting Kentucky, this time in a positive way for LGBTQ+ rights.

Also, dating back to 1792, throughout Kentucky's entire history, 'sodomy' has been illegal in the state. Though technically applying to any individual in the state who participates in acts that are considered sodomy, these laws have more recently been considered to be active measures to outlaw homosexual sex acts. Kentucky's sodomy law, which was most recently revised in 1974, considers 
sodomy in the fourth degree, a Class A misdemeanor, to have occurred when someone "engages in deviate sexual intercourse with another person of the same sex" (KRS § 510.100, 1974). The Supreme Court ruled in Lawrence v. Texas in 2003 that this law and others similar to it are violations of the Due Process Clause (Lawrence v. Texas 2003).

The above examples outline how the concept of preemption has had a highly visible history with LGBTQ+ rights. If Tennessee, Arkansas, and North Carolina are taken as examples, it is conceivable that Kentucky's legislative bodies may choose to pass such a prohibitory law, thus immediately making void all of Kentucky's active fairness ordinances and making repeal of this potential law the only recourse for Kentucky's fairness advocates.

As of the end of 2019, Kentucky's governorship has changed from Republican to Democratic, with the new governor having shown some, though not forceful, support for LGBTQ+ rights and equality of legal protections (Kentuckians for the Commonwealth 2020). At the same time, however, Republicans hold a veto-proof majority in the state General Assembly as well as the office of the Attorney General. The state of the Attorney General's office is crucial to civil rights issues as it has a significant say in state-level suits.

As a result, if the Kentucky legislature were to pass any sort of preemptive law seeking to make illegal any municipal fairness ordinances, the likely result would be a veto from Governor Andy Beshear, who has supported LGBTQ+ rights in the past (Riley 2020). Time would tell if the Republicans in the general assembly 
would vote to override that veto. In any event, the final say in such a law would rest in Republican hands.

Currently, bills have been filed in both chambers by Democrats that would create a statewide fairness law and ban conversion therapy (Riley 2020). Governor Beshear has expressed his support for these bills, should they be voted on and appear on his desk (Riley 2020). At this point, however, the conservative majority has not acted on the filings and the bills remain moot.

\section{Judicial Action}

LGBTQ+ civil rights have not gone without making an impact on the United States judicial system as well. Individual civil liberties like those of the LGBTQ+ fall under the purview of significant judicial decisions, the most notable being Obergefell v. Hodges (2015). This landmark case is commonly known as the one that made same-sex marriage legal, thus making obsolete many legislative discussions in various states regarding the legality of same-sex marriage. While same-sex marriage is settled law as a result of this case and is not immediately relevant to the purposes of this research, the opinions of the case hold significant constitutional authority that may be relied upon in efforts to support fairness ordinances, as well as by those who seek to oppose them.

The majority asserted that throughout history, there has been a "transcendent importance of marriage" (Obergefell v. Hodges, 576 U.S. (2015)). This remains true in the United States, as well as for many LGBTQ+ people. The respondents in this case claimed that extending marriage to samesex couples would demean the long history of the institution. In truth, the 
petitioners in this case, who were multiple same-sex couples, "seek it [marriage] for themselves because of their respect for it and need for its privileges and responsibilities" (Obergefell 2015).

The constitutional arguments of the petitioners rested on the Equal Protection and Due Process Clauses of the Fourteenth Amendment. The majority argued that the framers of the Fourteenth Amendment could not have known all forms of injustice that would ultimately arise, and thus sought to create a framework that could be relied upon to combat them (Obergefell 2015). The rights of the LGBTQ+ fall into this category, as those individuals and their rights were certainly not in the purview of Reconstruction Era constitutional theorists (Obergefell 2015). The majority found a clear dissonance between Constitutional protections and legal frameworks, thus necessitating action (Obergefell 2015).

Most conclusively, they cited Loving v. Virginia (1967) in making a ruling regarding interracial marriages, a "unanimous court held that marriage is 'one of the vital personal rights essential to the orderly pursuit of happiness by free men"' (Obergefell 2015). The Court then recognized that it is a body that makes certain assumptions based on the time of decision (Obergefell 2015). Accordingly, the Court found it prudent to make a ruling on same-sex marriage, something that was not explicitly protected by Loving. This ethos is the crux of the argument, at least regarding the situation at hand in this research. The Court found that a codified protection for a civil liberty can be extrapolated to issues of civil liberties that had not arisen at the time of writing of that protection. Accordingly, protections for the 
rights of LGBTQ+ citizens beyond simply the right to marry can be considered as intrinsic as any other liberty afforded to American citizens.

A clear argument against this finding can be found in Chief Justice Roberts' dissent in the case. He asserts that the Court, and the judicial system at large, does not and should not have a hand in deciding whether or not same-sex marriage should be the law of the land. He views that the majority has essentially legislated a nation-wide requirement that should have been borne out in proper legislative channels. While this argument can certainly seem disheartening for any advocate for expanded civil rights and liberties, it is not without its merit; Justice Roberts makes a valid point that an empowered and emboldened judicial branch has few checks and can wreak havoc upon the powers and duties of other branches of government.

\section{Sociocultural Factors}

The Prevalence of Religion

One of the most commonly cited oppositions to expansion of civil rights to LGBTQ+ people is based on deeply-held religious beliefs. National-scale expansion of civil rights has even been met with condemnation from the Vatican, arguably the single most concentrated sources of religious authority (INCLO 2015, p. 1). This stance of opposition is also seen on vastly smaller scales, including refusals to carry out public duties, fulfill business obligations, and otherwise offer equal services to LGBTQ+ people, all from a religious opposition (INCLO 2015, p. 4). 
The International Network of Civil Liberties Organizations (INCLO) recognizes that the state cannot dictate the beliefs held by citizens in the United States. However, this does not allow private citizens to freely discriminate. "Religious freedom does not give us the right to impose our views on others, including by discriminating against or otherwise harming them" (INCLO 2015, p. 5). This is not an all-consuming principle, however. Though religion cannot be a license to discriminate, the issue can be reversed by unfairly forcing a religious individual to do something against their deeply-held beliefs.

The INCLO recognizes that this still creates difficult legal conundrums. First, can a government employee be given an exemption to giving service to an LGBTQ+ person for religious reasons without that putting the "government's imprimatur on the conduct" (INCLO 2015, p. 5)? In other words, giving an exemption here could imply a tacit endorsement of a given religiom, something that is clearly unconstitutional. The INCLO comes to the conclusion that "government officials ... should not be afforded an exemption" because that would create an inexcusable public endorsement of religion (INCLO 2015, p. 6).

Second, it is important to consider the cost of accommodating a private individual's religious beliefs. This is the much murkier task. According to the INCLO, "individuals should be accommodated where doing so does not result in harm" $(2015$, p. 6). This is the sphere wherein we have seen, especially recently, a massive amount of legal action. No definitive answers have been found judicially regarding whether businesses may reject service to LGBTQ+ individuals. Until 
then, we are likely to continue seeing high profile examples of discrimination in the name of faith.

The answer to these issues is of course as murky as one might imagine. Religion can only be held to be a compelling argument in certain cases, and particularly only when the institution in question is a private, religiously affiliated organizations. Non-religious businesses and public institutions may not choose to ignore anti-discrimination laws merely due to religious preference. (INCLO 2015, p. 23). This shows that fairness ordinances, like any anti-discrimination legislation, may not be opposed merely due to religious arguments; the law itself takes precedence over these concerns.

This has not kept the effects of religion from being felt in local policymaking, however. Kentucky's fairness ordinances all include provisions that effectively exempt religious institutions from adhering to their provisions. This is done in clear language. The Georgetown, Kentucky ordinance, for example, states that "the provisions of this chapter regarding sexual orientation and gender identity shall not apply to" a religiously affiliated organization (Georgetown 2019). Lexington's ordinance shows a clear example of how including religious exemptions can expand support for these laws. It was only due to amendments making accommodations for religious organizations that some votes on the council were secured (Bennett 2011, p. 66). Kentucky lawmakers have not made any attempts to prohibit these sorts of exemptions, something that would almost certainly encounter friction with the sizable conservative population and would likely lead to lengthy court battles. 
Understanding the Lack of Diversity in Rural Areas Reveals a Need for a Statewide Law

The Movement Advancement Project's ("MAP") report, "Where We Call Home: LGBT People in Rural America (2019) outlines many of the disadvantages typically felt by rural LGBTQ+ Americans chiefly due to where they live. Many of these disadvantages can be directly applied to Kentucky's demographic make-up and offer insight into why Kentucky ought to implement a statewide nondiscrimination law.

Rural Americans tend to be Republican and are less likely to support LGBTQ+ policies (MAP 2019, p. 51). According to MAP, 54 percent of registered voters in rural counties are Republican or Republican-leaning. This is compared to 45 percent in suburban areas and 31 percent in urban areas (MAP 2019, p. 51). This trend has been seen in Kentucky and is becoming starker as time has passed. Counties identified as being 'very low density' are becoming less and less likely to vote for Democratic gubernatorial candidates (Montgomery 2019). While voting Republican does not necessarily indicate an opposition to LGBT-friendly policies, research has shown that Republican voters are less likely to think that these policies are 'good for society' (MAP 2019, p. 52).

MAP proceeds to recognize that Republicans in rural counties are yet more likely to call LGBT-friendly policies 'bad for society' than their suburban or urban counterparts. Seventy-one percent of rural Republicans call these policies a negative trend, while in suburban and urban settings, sixty-two and fifty-six percent, respectively, of Republicans hold those views (MAP 2019, p. 52). This 
indicates a problematic phenomenon, where Republic voters in rural settings are more likely to hold more conservative views than those urban settings.

\section{Examining Henderson}

It's fairly difficult to pinpoint what changed over the twenty-year time period to make passing Henderson, Kentucky's fairness ordinance possible. As this research remarked above, there was significant conservative backlash against the initial passage. In 2019, however, that conservative group was no less present than in 1999, though their opposition was far less outspoken.

Bill Patterson, the leader of the Green Valley Baptist Association, was a staunch opponent of both the 1999 and 2019 iterations of the law. He claims that a "significant cultural shift" had occurred that may have contributed to a lessening of political fervor against the law (Kenning 2019). Patterson remarked that even though many felt the same way as they had twenty years prior, many worried they would be "labeled a homophobe", thus discouraging speaking out against the ordinance (Kenning 2019).

The simple answer to why the 1999 ordinance ultimately failed but the 2019 one succeeded is that the city Commission's political make-up had shifted, from 32 against the ordinance to 3-2 in favor (Kenning 2019). The reality is, of course, still more nuanced. A major contributor to expanding acceptance of LGBTQ+ people is simply an increased knowledge and public recognition regarding the issues. Though urban citizens are more likely to have a close friend or family member who is LGBTQ+, increased visibility of minority populations has led to 
more rural citizens being able to say that they know an LGBTQ+ person. For example, in 2017, 57 percent of rural citizens surveyed claimed to have an LGBTQ+ friend or family member (MAP 2019, p. 51). Research has shown that this makes a difference and simply knowing someone who is LGBTQ+ can reduce prejudice toward those citizens and raise support for LGBT-friendly policies (MAP 2019, p. 51).

This increased visibility has been felt in Henderson as well. Kenning (2019) remarked on how citizens were being faced with the evolution of the issue in the past twenty years as LGBTQ+ people were becoming more visible in Henderson. As acceptance and visibility becomes the norm, support for the fairness ordinance became easier to find (Kenning 2019). One interviewee even remarked that the failed ordinance initiated difficult conversations on the topic, thus allowing them to reverse their opinion on the matter in 2019 (Kenning 2019).

While there may have been some cultural changes, a significant number of urban voters are still staunchly against LGBTQ+ protections. A 2017 study by the Public Religion Research Institute shows that 62 percent of rural Americans support nondiscrimination measures, compared with 72 percent of urban residents (Kenning 2019). This may be a majority, but a loud and vocal conservative minority can still have a significant political voice.

\section{Administrative Factors}

Accompanying the bevy of legislative actions regarding nondiscrimination are appropriate administrative measures that are taken to aid in the enforcement of such legislation. Generally, these have been written into the individual fairness 
ordinances. Additionally, Kentucky's governors have taken preemptive action to make unilateral orders regarding LGBTQ+ rights.

\section{Louisville and Lexington-Fayette's Approach}

Both Louisville and Lexington-Fayette County's ordinances were established under the purview of their respective Human Rights Commissions, boards of appointed members "who are as nearly as possible representative of the several social, economic, cultural, ethnic and racial groups" of the county (Lexington-Fayette County 1999). The Louisville-Jefferson Metro ordinance, which was re-established in 2003 when the city and the county governments were merged, empowered the Louisville Metro Human Relations Commission with the ability to enforce the fairness ordinance (Louisville 2003).

Section 2-33 of Lexington's ordinance is the local fairness ordinance and specifically discusses factors relating to sexual orientation and gender identity (Lexington-Fayette County 1999). The board acts, essentially, as a decisionmaking administrative body that hears complaints, holds hearings, and issues decisions (Lexington-Fayette County 1999). Establishing fairness ordinances under the purview of similar commissions is a practice that has been seen repeatedly in the two decades to follow.

On a statewide level, Kentucky already has the mechanisms to mirror the approach of Louisville and Lexington. Kentucky's Commission on Human Rights, established first in 1960 and re-established in 1966, shows a similar administrative framework as has been seen in municipalities like Lexington-Fayette County (KTS 344, 1966). The Commission on Human Rights was initially created in 1960 and 
re-established in 1966 by the Kentucky Civil Rights Act. This act highlighted the importance of the commission and its ability to "foster respect among and to discourage discrimination against any racial or ethnic group and its members" (KRS 344.170 1966). Since then, the commission has been granted authority over issues concerning women (KRS 344.510-530 1998), sex equity in education (KRS 344.550-575 1990) and discrimination in housing (KRS 344.600-680 1994).

Accordingly, a statewide law could take inspiration from fairness ordinances and grant the Commission that authority to address disputes regarding discrimination and civil rights. The Lexington-Fayette County ordinance grants its Commission powers including "the jurisdiction to receive, investigate, conciliate, hold hearings and issue orders relating to complaints" (Lexington-Fayette County 1999, Ch. 2 Art. II Sec. 2-33) when it comes to discrimination regarding employment, public accommodation, or housing.

Administrative Steps from Across the State

Georgetown's ordinance followed the pattern set by Lexington-Fayette County. In its text, it empowers the mayor to "lawfully establish a local Human Rights Commission OR (emphasis original) enter into Interlocal Agreements with other agencies" (Georgetown 2019, p. 11). The resulting public agency would have the ability to hear complaints brought on by aggrieved parties that were not resolved via another agency or federal court (Georgetown 2019, p. 11). As of November of 2019, two months after the passage of the law, the city has announced that it will create a Human Rights Commission in accordance with the law (LEX18 2019). 
Paducah's fairness ordinance also directly established their own Human Rights Commission composed of five members (Paducah 2018, p. 135). As part of its General Duties, this commission "shall endeavor to promote and secure mutual understanding and respect among all economic, social, ethnic, religious, and racial groups in the city, including those representing gender identity and sexual orientation" (Paducah 2018, p. 136).

Henderson and Maysville similarly empowered a commission to handle complaints under its law. They differ from the above examples, though, in that both cities had pre-existing human rights commissions (Henderson 2019, Maysville 2018), with Henderson's existing all the way back through 1962, only two years younger than Kentucky's (Henderson 2019).

Henderson's commission is empowered to investigate complaints and, granted the existence of probable cause, come to a settlement amongst the involved parties (Henderson 2019). The next step taken by the commission would be to hold a formal hearing on the matter (Henderson 2019).

Maysville's commission, on receiving a complaint of discrimination based on gender identity or sexual orientation, will contact the Respondent and expect a written response (Maysville 2018). Notably, any discrimination based on other grounds, such as race, gender, or age is sent to the Kentucky Commission on Human Rights, a clear example of the differences of enforcement based on the members of the harmed party (Maysville 2018). Similar to Henderson, the Maysville commission will then pursue a conciliatory phase with a potential for formal hearings (Maysville 2018). 
The city of Dayton has taken a more restrained approach compared to Lexington-Fayette County. Dayton does not empower a multi-member commission to investigate wrong-doing. Instead, after investigation occurs, the City Administrator shall make a ruling based on the evidence (Dayton 2019, p. 8). If misconduct is found, the administrator will initiate a conciliation settlement that, if not successful, may lead to a hearing in accordance with the Kentucky Civil Rights Act (Dayton 2019, p. 8).

Midway's ordinance makes allowances for the involvement of a multimunicipal commission entitled the Versailles-Midway-Woodford County Human Rights Commission, but only in cases involving race, color, religion, national origin, sex, familial status, age, or disability (Midway 2013). The damaged party in a discrimination complaint relating to gender identity or sexual orientation will take their case to Midway's mayor who will then oversee, directly or indirectly, a proper investigation of it (Midway 2013).

Danville's fairness ordinance empowers the city manager or any of its designees to oversee complaints (Danville 2013). The agent will follow similar procedures to those seen in the ordinances outlined above (Danville 2013). Again, any other claims of discrimination besides those based on sexual orientation or gender identity are to be referred to the State Human Rights Commission (Danville 2013).

In Morehead, the same pattern continues where the city will "reserve to itself the resolution of all claims of discrimination based on sexual orientation or gender identity", while other forms of discrimination are sent to the Kentucky Commission 
(Morehead 2013). Frankfort, another ordinance from 2013, tries the other method that has emerged by establishing and empowering its own Human Rights Commission that will review and hear any disputes (Frankfort 2013, p. 64C).

In 2003, Covington established its ordinance along with its own Human Rights Commission (Covington), showing that the influence of Lexington and Louisville's approach was felt by the next successful fairness ordinance. The City Manager of Covington was tasked with reviewing incoming complaints and designating an agent to fulfill enforcement of the ordinance (Covington 2003). In Covington, complaints are ultimately heard by the Human Rights Commission, regardless of the form of discrimination (Covington 2003).

\section{Table 2}

$\underline{\text { Administrative Remedies Undertaken by various Ordinances }}$

\begin{tabular}{|l|l|l|l|}
\hline \multicolumn{1}{|c|}{ Year } & Municipality & $\begin{array}{c}\text { Administrative } \\
\text { Enforcement Method }\end{array}$ & $\begin{array}{l}\text { Is there a local/regional } \\
\text { commission? }\end{array}$ \\
\hline $\begin{array}{l}1999 \\
(2003)\end{array}$ & Louisville & Commission & Yes \\
\hline 1999 & Lexington & Commission & Yes \\
\hline 2003 & Covington & Commission & Yes \\
\hline 2013 & Frankfort & Commission & Yes \\
\hline 2013 & Morehead & $\begin{array}{l}\text { City Administration of } \\
\text { Case }\end{array}$ & No \\
\hline 2013 & Danville & $\begin{array}{l}\text { City Administration of } \\
\text { Case }\end{array}$ & No \\
\hline 2013 & Midway & $\begin{array}{l}\text { City Administration of } \\
\text { Case }\end{array}$ & Yes \\
\hline
\end{tabular}




\begin{tabular}{|l|l|l|l|}
\hline 2018 & Paducah & Commission & Yes \\
\hline 2018 & Maysville & Commission & Yes \\
\hline 2019 & Henderson & Commission & Yes \\
\hline 2019 & Georgetown & Commission & Yes \\
\hline
\end{tabular}

Louisville (2003), Lexington (2009), Covington (2003), Frankfort (2013), Morehead (2013), Danville (2013), Midway (2013), Paducah (2018), Maysville (2018), Henderson (2019), Georgetown (2019)

Statewide Administrative Orders

Active laws to protect LGBTQ+ people have been virtually nonexistent in Kentucky. Administrative orders, however, have occurred in the past in order to offset reports of discrimination. In 2003, when Kentucky cities were about to go on a ten-year hiatus from passing any more fairness ordinances, Governor Paul Patton, a Democrat, issued an executive order prohibiting public employment discrimination based on sexual orientation or gender identity. This order would be revoked by Governor Ernie Fletcher, a Republican, and then re-issued by the following Democratic governor, Steve Beshear (Beshear 2013, p. 1).

Governor Beshear's executive order was framed as an 'affirmative action plan' that would "provide for equal employment opportunity to all people in all aspects of employer-employee relations without discrimination" (Beshear 2013 p. 1). These protections were guaranteed to all employees of every Kentucky cabinet, department, or agency and enforcement was left up to the Secretary of the Personnel Cabinet (Beshear 2013, p. 2). This administrative action is the only example of statewide discrimination protection in Kentucky and no other measures have been passed or enacted since.

The Reality of Statewide Fairness in Kentucky 
In two decades of Kentucky fairness, patterns have developed in the design of these ordinances. Overall, there is a large degree of conformity between them as they all tend to show the same, or nearly identical language. According to Wales (2017), this is largely due to the efforts of not only the Fairness Campaign, but also the ACLU of Kentucky. The ACLU has been dedicated to ensuring that every fairness ordinance passed covers gender identity as well as sexual orientation (Wales 2017, p. 30-31). As a result, all of Kentucky's ordinances through 2019 cover both sexual orientation and gender identity. The progressiveness of Kentucky's municipalities on this issue is remarkable. All told, thirty percent of Kentucky's citizens are protected in their places of employment by fairness ordinances. By comparison, of the twenty-six states that do not have state laws preventing passage local nondiscrimination laws, only six have a higher percentage of protected citizens. A relatively similar picture is painted when looking at housing and public accommodation (MAP Equality Maps 2019). This marks Kentucky as a surprisingly progressive state on this issue, at least so far as keeping up with the LGBTQ+ protection experienced in other, more liberal states (MAP Equality Maps 2019).

This progressiveness of the state's cities is striking due to the degree that statewide lawmakers have avoided tackling this same issue (Riley 2020). No legislation exists to protect LGBTQ+ citizens from discrimination based on their sexual or gender identities, while recent efforts are being essentially ignored by the conservative majority (Riley 2020). In fact, a 2004 Kentucky constitutional amendment, approved by 75 percent of the citizenry, formally recognized a 
marriage as being between a man and a woman. Section 233A of the Kentucky Constitution dictates not only that a marriage is to only be between a man and a woman, but also that "a legal status identical or substantially similar to that of marriage for unmarried individuals shall not be recognized" (Kentucky Constitution 2004,233 A). This expansive view would, by its text, serve to outlaw such options as civil unions, seen by many prior to Obergefell $v$. Hodges as a possible alternative to marriage. It should be noted, of course, that this provision has been superseded by that same judicial ruling. Still, Section 233A remains on Kentucky's Constitution as a symbolic reminder to many of Kentucky's complicated political reality. 


\section{CHAPTER V \\ ANALYSIS: DESIGNING A KENTUCKY LEGISLATION}

The Benefits of Uniformity

In this research's Methods section, it was said that both similarities and a lack of similarities amongst Kentucky's fairness ordinances would be instructive for designing a fairness law for the state. Upon reviewing Kentucky's history of such ordinances, it has become increasingly clear that they have more similarities than they do differences. In most cases, they use exactly the same text as each other. For city-level ordinances, this is a wise course of action. Pursuing visually identical other municipalities allows city officials to rely upon the examples set by neighboring cities and avoids appearing too radical.

The uniformity is, of course, also due to the influence of organizations such as the Fairness Campaign. They anticipate potential backlash, including judicial and legal attempts to remove the fairness laws from the record. By passing multiple ordinances across the state with virtually the same text, the Fairness Campaign preemptively creates an argument for themselves. If a person, business, or group brings suit against one city's ordinance, then the city in question, and perhaps the Fairness Campaign via an amicus brief, can argue that other cities have taken the exact same measures into their own records. This reality can act as a deterrent against courts deciding against a city's ordinance as it would open up additional 
legal proceedings all across the state. Or, if taken to the appellate level, it may result in a high-publicity decision that would potentially decide the fate of such laws in the state.

This uniformity is also useful directly towards development of a statewide law. It contributes to an additional purpose beyond merely protecting the citizens of a given city from discrimination. It turns the state's cities and counties into a testing ground for such legislation. Historically, a strong argument against invoking state and federal supremacy is that lower governments should decide what is best for themselves and their own citizens.

This is exactly what Kentucky's cities have done in the last two decades. The state government has left it up to the cities to decide on nondiscrimination measures for themselves. As it becomes more and more clear that Kentucky's citizens either are or will soon be covered by fairness ordinances, the argument becomes stronger for a statewide equivalent. Passing a state law would free up administrative and judicial resources that are unnecessarily tied up in reacting to discrimination cases across the state. Even in recent cases where Kentucky courts have had the opportunity to answer these questions with some degree of finality, they have not made any significant decisions that would alter the complicated present. The patchwork that is the protections experienced by LGBTQ+ Kentuckians creates difficult court cases (Austin 2019) that further divide conservative citizens from LGBTQ+ citizens and their advocates.

Kentucky's Nondiscrimination Law 
In this section, the ultimate goal of this research will be undertaken; designing a suitable statewide nondiscrimination law. The literature referenced above has delved into the myriad facets that make up Kentucky's fairness ordinances. While a few may have their unique quirks and peculiarities, their uniformity rings louder than their differences. As a result, the best course of action would be to adopt the uniform language in a way that can be deemed acceptable across the state.

\section{Definitions}

The bedrock of such a law, or any law, would rest on the definitions of its foundational terminology. In this situation, focus will be primarily granted to sexual orientation and gender identity. It is vital that these definitions are congruent with common conceptions held by LGBTQ+ people or the legislation would surely fail in enforcement as the claims of anyone who may experience discrimination would become tied up or ultimately fail due to ambiguity in the wording.

While any of Kentucky's fairness ordinances may be chosen as an example of these definitions, the most recent ordinances will be relied upon, as, presumably, they would feature the most current conception of these identities. Here is how Henderson defined sexual identity: "an individual's actual or imputed heterosexuality, homosexuality or bisexuality" (Henderson 2019, Article IV Sec. 10-41). This definition is a strong starting point, and though it does omit numerous identities, it is a reasonable legal summarization of sexual identities, if slightly vague on what constitutes 'heterosexuality, homosexuality, or bisexuality'. 
Henderson's gender identity definition reads: "a person's gender-related mannerisms, appearance, style of dress, characteristics, or identity, without regard to the person's designated at birth" (Henderson 2019, Article IV Sec. 10-41). This, as opposed to the prior definition, is a more than adequate summation of what constitutes a gender identity. First, it recognizes some of the various aspects that are involved in a person's gender expression beyond simply the visual. Second, and more importantly, it clearly does not rely on a binary definition of gender. It recognizes instead that a gender identity that is divergent from cisgender is one that simply does not match the gender assigned at birth. This opens the door to protections for people anywhere on the gender spectrum, whether they identify as binary-gendered or not, or even if they do not identify as a gender.

In addition to the above two definitions, there is another definition from the Henderson ordinance that would serve well statewide. Defining what constitutes an 'employer' would be prudent because this definition has been the most notable example of disparity between the various fairness ordinances. When considering the diversity of this definition across the state, with the highest examples being fifteen employees and the lowest being just one, Henderson serves as a good middle ground. The ordinance calls an employer "a person who has eight or more employees within the state in each of twenty or more calendar weeks in the current or preceding year or an agent of such person" (Henderson 2019, Article IV Sec. 10-41). A 2015 study showed that seventeen percent of Kentucky's employment firms employ between one and nineteen people (Small Business Administration 2015, fig. 1). Defining an employer as having eight or more employees is a good 
choice for this legislation as it comfortably covers, at a minimum, eighty-three percent of Kentucky's employers. Also, it relies upon the model that has been employed by the Kentucky Commission on Human Rights (KRS 344.030 2019).

In summation, the three vital definitions for the state law are:

- Sexual Orientation: an individual's actual or imputed heterosexuality, homosexuality or bisexuality, be it in action, identity, or description, perceived or real;

- Gender Identity: a person's gender-related mannerisms, appearance, style of dress, characteristics, or identity, without regard to the person's designated at birth; and

- Employer: a person who has eight or more employees within the state in each of twenty or more calendar weeks in the current or preceding year or an agent of such person.

In addition to these three, other definitions will certainly be involved in the writing of a fairness bill. These other definitions may be researched and chosen from the state's fairness ordinances as, again, the ordinances exhibit notable uniformity across the board.

Empowering the Kentucky Commission on Human Rights

Taking inspiration from many of Kentucky's fairness ordinances, the state law will be passed under the purview of the Kentucky Commission on Human Rights. This will ensure a significant amount of control in the process is held by administrative officials. As was discussed in this research, the commission was originally designed to "foster respect among and to discourage discrimination 
against any racial or ethnic group or its members" (KRS 344.170 1966) and to also oversee issues regarding women (KRS 344.510-530 1998), sex equity in education (KRS 344.550-575 1990) and discrimination in housing (KRS 344.600680 1994).

Looking to the state's fairness ordinances, and in particular the one passed in Lexington-Fayette County, the purview of the Kentucky Commission on Human Rights will be expanded to concern discrimination on the basis of sexual orientation or gender identity in employment, housing, or public accommodation.

This would be a marked expansion of the scope of the Commission's current outlook on what constitutes discrimination. As currently defined by Kentucky's Statutes, 'because of sex' and 'on the basis of sex' merely relate to child-bearing and -rearing related statuses, making illegal such acts as discriminating against a pregnant person or a person requiring leave for childbirth (KRS 344.030 2019). Not only is this a profoundly restrictive view on what constitutes discrimination on the basis on biological sex, it clearly leaves out any text relating to sexual orientation or gender identity. As can be seen by example in the Lexington-Fayette County Human Rights Commission, this text shall be expanded to include, specifically, a prohibition on "discrimination on the basis of sexual or gender identity within" (Lexington-Fayette County 1999, Ch. 2 Art. II Sec. 2-33) the state of Kentucky.

Taking further guidance from the Lexington-Fayette ordinance, the Commission's powers will include "the jurisdiction to receive, investigate, conciliate, hold hearings and issue orders relating to complaints" (Lexington- 
Fayette County 1999, Ch. 2 Art. II Sec. 2-33) in regards to discrimination relating to employment, public accommodation, or housing. If the Commission believes that a discriminatory act has indeed occurred, the injured party is granted standing for a civil cause of action in the Circuit Court to recover suitable damages (KRS 344.450 1996). This would be the mechanism by which discriminated parties would formally seek recompense. They would file a complaint with the Kentucky commission and, given a hearing judgment in their favor, would be able to litigate their case via the judicial system. As it is currently, without affording complaints on account of sexual orientation or gender identity, LGBTQ+ find themselves with little standing with the Commission. 


\section{Exceptions}

On the issue of religious organizations, it is clear that the statewide law will have to enact exceptions. The common practice among the state's fairness

ordinances has been to include a provision allowing that they do not apply to religious and charitable institutions. This has been largely done to assuage citizens in favor of religious freedom who may believe that employing, housing, or serving certain LGBTQ+ people would conflict with their religion.

It is only a matter of time before such a conflict reaches a high level of appellate court and establishes case law regarding who a business can or cannot turn away on religious grounds. Until that point, this exception is necessary in order to convince many religious conservative citizens of Kentucky to support, or at least not outright oppose, this law (Bennett 2011, p. 66).

The Kentucky Commission on Human Rights does have safeguards in place relating to this, however. As can be seen in Chapter 344.130 of the Kentucky Revised Statutes, "'place of public accommodation, resort, or amusement' does not include a religious organization" that either teaches or advocates hatred based on race or ethnicity or otherwise excludes certain groups of people from participating (KRS 344.130 2000). This stipulation keeps religious organizations from having too much latitude in deciding their stance on LGBTQ+ matters, ensuring that they cannot openly discriminate. These safeguards should be expanded in the new law to include protection for LGBTQ+ people. 


\section{CHAPTER VI}

\section{CONCLUSION}

The research above outlines a framework that Kentucky legislators and administrative officials can follow to implement an effective statewide nondiscrimination law. Kentucky's various fairness ordinances to this effect have served multiple, underlying purposes. First, they have worked as a testing ground for effective local legislation, something that many constitutional scholars consider to be a benefit to leaving many legislative choices up to lower levels of government. Second, they have created a consensus regarding what specific language works in Kentucky for nondiscrimination laws. Both their similarities and differences are highly revealing regarding what constitutes an effective Kentucky nondiscrimination law, highlighting such factors as agreed upon definitions of sexual orientation and gender identity, administrative oversight of the laws themselves, and implementing reasonable exceptions to the law.

\section{Implications}

The implications of this research involve a deeper understanding of the union between public administrators and the provision of civil rights protections. Most of Kentucky's fairness ordinances have either implemented or otherwise employed local commissions that are granted authority to review claims of discrimination. The other municipalities have still chosen to rely on administrative 
officials by handing decision-making power to executive officials and their agencies. Kentucky's statewide administrators should be equally utilized, as was described by the legislation outlined by this research. This represents the primary strategy that administrators can utilize to argue for their role within a potential fairness ordinance.

The Kentucky Commission on Human Rights would be granted the authority to review cases of discrimination based on sexual orientation and gender identity, just like all the other forms of discrimination that Kentucky law considers illegal. This approach would unify the legislation that has been explored in the last two decades across Kentucky into one law that follows from their examples.

Another implication of this research is the necessity of placing the civil rights of LGBTQ+ citizens on par with all other existing forms of civil rights in Kentucky. In its current state, civil rights protections in Kentucky is akin to a jumbled mess due to the disparate protections felt in some cities and not others. State administrators and legislators should give the ideas put forth in this research their proper due in order to best serve the Commonwealth's citizens.

By doing so, administrators may accomplish the final implication of this study: a route toward the unification of Kentucky's fairness ordinances. Trends in Kentucky have shown that progressive legislation is increasing, not slowing down in Kentucky, as numerous fairness ordinances have already been passed in the first few months of 2020 (Fairness Campaign 2020). Statewide legislation is appearing more inevitable than ever and research, including this paper and many more to likely follow, will aid in that effort. 


\section{Recommendations}

Based on the research above, a series of recommendations can be made, both for future research and for administrators in Kentucky. The first future research option lies in the fact that Kentucky cities have continued to pass fairness ordinances. This research analyzed ordinances passed through most of 2019 , but a number have been passed since then (Fairness Campaign 2020). The same analysis accomplished through this research may and should continue to be applied to those new ordinances to maintain the latest information on trends of civil rights in the state.

Secondly, the fairness ordinances could potentially encounter legal challenges within their respective jurisdictions. Such an even would provide a wealth of information for administrators and legislators to refer to when designing future civil rights legislation. It would also add to the research base by providing an example of a failed ordinance in addition to Henderson's.

A third avenue for future research lies in the applicability of this research method to other states. This same process can be transplanted to a number of other states in the nation who are in a similar situation without state-level direction on LGBTQ+ civil rights.

This research also puts forth a series of recommendations for Kentucky's administrators and legislators, including drawing on the experiences of their peers, tackling the problem from a bottom-up rather than top-down approach, and following the model of other forms of civil rights law. These recommendations are rooted in preserving the efforts that Kentucky's cities have so far attempted and 
succeeded with. State officials should recognize that the cities have already accomplished a great deal and their work should be honored and properly utilized.

The numerous fairness ordinances have been examined for their merits and weaknesses. Generally, they all have done well to progressively outline the specific protections needed for LGBTQ+ people; namely, the same nondiscrimination protections enjoyed by the nation's other minorities. While some of the ordinances were too conservative in their protections, they provided a valuable comparison to those that may be, in some ways, even too progressive. Twenty years of workshopping this very issue has given Kentucky administrators ample data to work with. The time has come to move decisively toward unifying all of Kentucky's municipality under a single, effective nondiscrimination law that recognizes the truly diverse citizenship of the state. To do otherwise borders on administrative waste as the state will perpetuate a reality of confusing, unequal protections.

The legislative outline above, as well as its accompanying research, will serve as a vital tool toward passing a statewide nondiscrimination law. Administrators should recognize the extreme degree of uniformity across all of the state's ordinances and use that to formulate a unified law. In reality, the state's cities have done the majority of the work; the text is out there and is ready to be accommodated toward the state legislature. 


\section{REFERENCES}

Austin, E. (2019, November 1). Kentucky supreme court sides with print shop owner who refuse to make a gay pride t-shirt. Courier-Journal. Retrieved from https://www.courier-journal.com/story/news/2019/11/01/kentuckysupreme-court-dismisses-gay-pride-t-shirt-case/4122844002/

Bennett, M. (2011). Fighting for fairness: The history of Kentucky's local movements to enact fairness ordinances in 1999. Western Kentucky University Honors College Capstone Experience/Thesis Projects. Retrieved from https://digitalcommons.wku.edu/cgi/viewcontent.cgi?article=1382\&amp;co ntext=stu_hon_theses.

Bertrand, M., \& Mullainathan, S. (2004). Discrimination in the job market in the United States. Abdul Latif Jameel poverty action lab. Retrieved from https://www.povertyactionlab.org/evaluation/discrimination-job-marketunited-states.

Bindley, K. (2012). Louisville girl attacked by adult, allegedly victim of anti-gay hate crime. Huffington Post. Retrieved from https://www.huffpost.com/entry/kentucky-victim-17attack_n_1686852?guccounter=1\&amp;guce_referrer=aHR0cHM6Ly93d3 cuZ29vZ2xILmNvbS8\&amp;guce_referrer_sig=AQAAACLjVaRoPOTHNP 
Qh768er6JdAQOOT7pufs8KrP0pffhITeeEMmrFVXDe5HDUsrRDChHAmo 3SM-

DBjmMIJ38nLwrt9HJ9nG5G47IAcJ5xv2ov6DQZZZSyqLvjpNk0UuS3Ltmt NHgeeKXpJrBb2MkV3G-ftNrYtWx20X3S-B-wJOke.

Constitution of the United States: A Transcription. (2019). National Archives.

Retrieved from https://www.archives.gov/founding-docs/constitutiontranscript\#toc-article-vi.

Chapter 2 Art. II Sec. 2. (1999). Lexington, Kentucky. Retrieved from https://library.municode.com/ky/lexingtonfayette_county/codes/code_of_ordinances?nodeld=COOR_CH2AD_ARTII LEYECOHURICO,

Chapter 5.5, Danville, Kentucky (2013). Retrieved from https://codelibrary.amlegal.com/codes/danvilleky/latest/danville_ky/0-0-016011\#JD_5.5-9.

Chapter 10 Art. IV Sec. 10. (2019). Henderson, Kentucky. Retrieved from https://library.municode.com/ky/henderson/codes/code_of_ordinances?no deld=COOR_CH10CIRI_ARTIVUNDIBASEORGEIDEMPUACHO_S1041DE.

Chapter 19-022, Georgetown, Kentucky (2019). Retrieved from https://www.georgetownky.gov/DocumentCenter/View/1081/19-022Fairness-. 
Chapter 37, Covington, Kentucky (2003). Retrieved from https://codelibrary.amlegal.com/codes/covington/latest/covington_ky/0-00-1892.

Chapter 92, Louisville-Jefferson County, Kentucky. (1999). Retrieved from https://codelibrary.amlegal.com/codes/louisvillemetro/latest/loukymetro/00-0-7720.

Chapter 94, Midway, Kentucky. (2013). Retrieved from https://codelibrary.amlegal.com/codes/midway/latest/midway_ky/0-0-06316.

Chapter 96, Frankfort, Kentucky (2013). Retrieved from https://www.frankfort.ky.gov/DocumentCenter/View/577/Frankfort-Title-IXGeneral-Regulations-PDF.

Chapter 96, Morehead, Kentucky (2013). Retrieved from https://codelibrary.amlegal.com/codes/morehead/latest/morehead_ky/0-00-5404\#JD_96.10.

Chapter 197, Maysville, Kentucky (2018). Retrieved from https://library.municode.com/ky/maysville/codes/code_of_ordinances?nod eld=CD_ORD_TITXIXPRPRRE_CH197EQRI_S197.02DE

Chapter 2018-1-8509, Paducah, Kentucky (2018). Retrieved from https://library.municode.com/ky/paducah/ordinances/code_of_ordinances? nodeld $=882277$. 
Chapter 2019 - \#14, Dayton, Kentucky (2019). Retrieved from http://www.daytonky.com/wp-content/uploads/2015/04/Ordinance201914.pdf.

EEOC. (1964). Title VII of the civil rights act of 1964. Retrieved from https://www.eeoc.gov/laws/statutes/titlevii.cfm.

EEOC. (2015). Sex-based discrimination. Retrieved from https://www.eeoc.gov/laws/types/sex.cfm.

Executive Order 2013-841, Kentucky. (2013). Retrieved from https://personnel.ky.gov/Documents/Affirmative\%20ActionPlanExecutiveO rder.pdf.

Fairness Campaign. (2019). About us. Retrieved from https://www.fairness.org/about-us/.

GAO. (1990). Case study evaluations. Retrieved from https://www.gao.gov/special.pubs/10_1_9.pdf

Hayes, R., Kyer, B., \& Weber, E. (2015). The case study cookbook. Retrieved from https://web.wpi.edu/Pubs/E-project/Available/E-project-121615164731/unrestricted/USPTO_CookbookFinal.pdf.

Hunter, L. J. (2013, August 19). Gay mayor promotes LGBT fairness in smalltown Kentucky. The Washington Post. https://www.washingtonpost.com/blogs/she-thepeople/wp/2013/08/19/gay-mayor-promotes-lgbt-fairness-in-kentucky/ INCLO. (2015). Drawing the line: Tackling tensions between religious freedom and equality. Retrieved from 
https://www.aclu.org/sites/default/files/field_document/inc15-reportdrawingtheline-rel1.pdf.

Johnson, R. W., \& Gosselin, P. (2018). How secure is employment at older ages? Urban institute. Retrieved from https://www.urban.org/research/publication/how-secure-employmentolder-ages/view/full_report.

Kenning, C. (2019, June 21). What a Kentucky town's 20-year struggle with 'fairness' says about rural LGBTQ rights. Courier-Journal. Retrieved from https://www.courier-journal.com/story/news/2019/06/21/lgbt-rightsfairness-ordinance-divides-henderson-kentucky/1419857001/

Kocher, G. (2013, August 29). Frankfort passes fairness ordinance with 3-2 vote. Lexington Herald-Leader.

https://www.kentucky.com/news/local/counties/franklincounty/article44441559.html

KRS Chapter 344, Kentucky (1966-2019). Retrieved from https://apps.legislature.ky.gov/law/statutes/chapter.aspx?id=38920 KRS Section 233A, Kentucky (2004). Retrieved from https://apps.legislature.ky.gov/Law/Constitution/Constitution/ViewConstitut ion? $\mathrm{rsn}=268$.

KRS Section 510.100, Kentucky (1974). Retrieved from https://apps.legislature.ky.gov/law/statutes/statute.aspx?id=19767. Lawrence v. Texas, 539 US 558 (2003). 
LEX18 Web Staff. (2019). Georgetown to create human rights commission. LEX18. Retrieved from https://www.lex18.com/news/coveringkentucky/georgetown-to-create-human-rights-commission MAP. (2019). Equality Maps. Retrieved from https://www.Igbtmap.org/equalitymaps/.

MAP. (2019). Where we call home: LGBT people in rural America. Retrieved from https://www.lgbtmap.org/rural-lgbt/.

Montgomery, D. (2019). The urban-rural political divide is growing. Citylab.

Retrieved from https://www.citylab.com/equity/2019/11/election-resultssurburban-voters-rural-urban-density-index/601585/.

Obergefell v. Hodges, 576 U.S. (2015).

Riley, J. (2020). Kentucky governor calls for passage of nondiscrimination law and ban on conversion therapy. Metroweekly. Retrieved from https://www.metroweekly.com/2020/02/kentucky-governor-calls-forpassage-of-nondiscrimination-law-and-ban-on-conversion-therapy/.

Riverstone-Newell, L. (2017). The rise of preemption laws in response to local policy innovation. Publius: The Journal of Federalism. Retrieved from http://defendlocal.com/wp-content/uploads/2017/10/Rise-of-StatePreemption-Laws-in-Response-to-Local-Policy-Innovation.pdf.

Singh, S., \& Durso L. E. (2017). Widespread discrimination continues to shape LGBT people's lives in both subtle and significant ways. Center for American progress. Retrieved from https://www.americanprogress.org/issues/lgbtq- 
rights/news/2017/05/02/429529/widespread-discrimination-continuesshape-lgbt-peoples-lives-subtle-significant-ways/.

Small Business Administration (2015). Small business profile: Kentucky.

Retrieved from https://www.sba.gov/sites/default/files/advocacy/KY_0.pdf. USC Libraries. (2019). Organizing your social sciences research paper: Writing a case study. Retrieved from https://libguides.usc.edu/writingguide/casestudy.

Wales, C. (2017). LGBTQ+ nondiscrimination laws in Kentucky. (2874) [Master's thesis, University of Louisville College of Arts and Sciences]. Electronic Theses and Dissertations.

White, D. (2019, June 25). $11^{\text {th }}$ Kentucky city adopts fairness ordinance protecting LGBT residents from discrimination. Courier-Journal. Retrieved from https://www.courier-journal.com/story/news/local/2019/06/25/lgbtrights-henderson-kentucky-adopts-fairness-ordinance/1566687001/

Wooldridge, B., \& Gooden, S. (2009). The Epic of Social Equity. Administrative Theory \& Praxis (M.E. Sharpe), 31(2), 222-234. https://doiorg.echo.louisville.edu/10.2753/ATP1084-1806310205 World Population Review. (2019). Population of cities in Kentucky. Retrieved from http://worldpopulationreview.com/states/kentucky-population/cities/. 


\section{CURRICULUM VITA}

NAME:

Blake Nona Gould

ADDRESS: $\quad$ School of Urban and Public Affairs

426 W. Bloom Street

University of Louisville

Louisville, KY 40208

DOB: $\quad$ Louisville, Kentucky - August 17, 1993

EDUCATION

\& TRAINING: $\quad$ B.S., Political Science - Paralegal Studies University of Louisville

2012-16

PROFESSIONAL EXPERIENCE:

Real Estate Paralegal - May 2016-December 2017

Communications Assistant at UofL - February-

November 2019

Healthcare Legal Assistant - November 2019-Present 